Murie, A., Dieleman, F.M., \& Hooimeijer, P. (1991). Housing asset values and the mobility of elderly home owners: housing research and policy issues. Netherlands journal of housing and the built environment., 6(1), 21-34. 


\title{
HOUSING ASSET VALUES AND THE MOBILITY OF ELDERLY HOME OWNERS: HOUSING RESEARCH AND POLICY ISSUES ${ }^{1}$
}

\author{
Alan Murie, Frans Dieleman and Pieter Hooimeijer
}

\section{Introduction}

The growth in home ownership as part of the restructuring of housing tenure is a familiar theme in discussions of the ways in which housing has been changing in many countries. The expansion of home ownership has generally been encouraged by governments, and both the forms of subsidies and incentives and the greater mobility of younger households have meant that the growth in home ownership has been greatest among these households. Furthermore, where the growth in home ownership has been associated with unsubsidized speculative building, younger more mobile households are a major market group. Thus the age profile of home ownership, especially during its early growth phase, tends to be skewed towards younger persons, or at least to include few of those beyond middle age. As the tenure matures, however, so do the home owners. The same factors relating to mobility and family mean that older households are less likely to move. In addition, the advantages associated with home ownership are such that as the new generation of home owners ages they will tend to remain home owners. An increasing population of older people in home ownership arises through the ageing of the population already in home ownership rather than because many first-time buyers are elderly.

The age profile of the population of home owners raises new issues for research and policy. Arrangements which have proved popular and successful for younger people may need to be developed to suit those with fewer financial and physical resources and, perhaps, declining physical mobility. At the same time, some of the patterns of behaviour associated with home owners or with elderly people may change. In particular, the wealth stored in their housing potentially changes the housing and other options available to elderly home owners. Older people who own valuable properties would seem likely to have more choice in adjusting their housing situation to match changing needs and preferences. They are more likely to make changes to their existing dwelling; they are more likely to be able to purchase an alternative dwelling; they are also more able to participate in retirement migration; and they could participate in schemes which enable housing equity to be released for a variety of purposes.

Neth. J. of Housing and the Built Environment, Vol. 6 (1991) No. 1. 


\section{Elderly home owners in the Netherlands}

This paper is designed to raise questions about these issues in relation to the Netherlands. Home ownership in the Netherlands has grown steadily throughout this century. In $192017 \%$ of households owned their own homes; by 1949 the figure was $28 \%$, in $197035 \%$, and in 1985 it was $43 \%$.

For various reasons, issues relating to the elderly and home ownership have only recently begun to attract attention, and little detailed work has as yet been carried out. The importance for the housing market of demographic change and the growth of a large number of older, low mobility households has been identified (Hooimeijer et al., 1986; Dieleman, 1986; Dieleman and Schouw, 1986). There remains little discussion, however, of the significance of these trends for home ownership. The dominant perspectives on older people and housing refer to their low mobility. Households are at their most active in the housing market when heads of households are aged between 25 and 40. After that age, households enter a long period of low residential mobility, first as older families, then as families with children leaving, and finally as older two or one-person households. The duration of the final stage is becoming longer because households have fewer children and people are living longer. Between 1985 and the year 2000 many households will enter the stage of low residential mobility (Hooimeijer and Dieleman, 1986; Dieleman, 1986). While housing careers are made by the age of 40 this does not mean that no movement takes place after that. As Dieleman and Schouw (1986) argue, patterns of movement among the elderly in the future may not follow current patterns. Smaller families and changing neighbourhoods may reduce attachment to particular neighbourhoods. Increased affluence and wealth associated with home ownership may create new opportunities. Furthermore, if higher mobility among the elderly is associated with characteristics which will increase in importance - say home ownership - then some modification to the dominant low mobility perspective may be needed.

In a recent paper which focuses on households in the reduction stage it is suggested that the low mobility of these households is explained by the absence of demand for extra space and the fact that income has reached a more or less stable level by the age of 50 (Hooimeijer et al., 1988). This paper identified a number of features of moves made by older households and argued that further work was needed on the factors influencing the propensity of older households to move. Compared with younger households in the Netherlands, those in the reduction stage seem to have a greater preference for rented housing, irrespective of both income and age; those who own their house are less likely to move than tenants, but they are more likely to move if their house is older or is larger. They are also more likely to move if they live in urban areas - a feature which appears to relate to the supply of acceptable alternative housing. Although the mobility of all households in the reduction stage is low, the very old move least, and those aged between 63 and 78 years move most frequently. This is probably associated with bereavement, changes in health or changes in income following retirement. Nevertheless, tenure and quality of housing are 
more important than age in predicting mobility. Among home owners, household composition emerges as an important determinant of mobility.

When choice rather than mobility is analysed, a similar pattern emerges. Household composition, tenure of the previous dwelling, age of head of household and size of municipality are important, but income has only a small effect. First-time buyers are almost non-existent among these older households. Owners move into rented housing more often than tenants buy. They are less likely to move to rented housing if they are families. Where they do move to the rented sector they are more likely to move to a larger dwelling than tenants who move. This may reflect differences in expectations, but it may also relate to supply factors and the different patterns of choice available in different areas. One final observation about the housing behaviour of older people in the Netherlands relates to the striking lack of any equivalent to the kind of retirement migration evident in the United States of America, Britain and France.

\section{Issues for further investigation}

In view of the issues outlined above, there is a case for looking again at older people in housing and for exploring the behaviour of different groups of elderly home owners. It may be that income, which generally emerges as a major factor in housing behaviour (Deurloo et al., 1987), does not represent the key indicator of market position or bargaining power among the elderly that it does among those who are in work or unemployed. Rather than current income it would be past income derived from employment which would be significant in relation to the housing situation. This would be particularly true for home owners where the differences between (low) current incomes will be less than differences in lifetime incomes and in the value of the house they own. Also, for older households the capacity to increase borrowing in order to widen access is limited. The price obtained for a previous dwelling will be more critical in determining the range of choices open to them. It would seem likely that while older people in general have low mobility, the highest rate of mobility would be among those owning the highest value homes. In addition, the nature and direction of moves (in relation to dwelling size, type, age, value, location and tenure) is likely to be affected by this. The existing evidence suggests that household composition, age and local context should also be taken into account. The very old (those aged over 74) are likely to be less mobile, irrespective of the value of their property. And where they do move, this may be related more to changes in health and fitness or to changes in household composition following bereavement (Serail, 1988).

The implications of this discussion are that rather than be satisfied with a picture of older people in housing as a relatively uniform group who are disinclined to move, further analysis of the behaviour of home owners and some consideration of the effects on this behaviour of the value of their property, their age and their household composition is called for.

Before presenting data related to this it is appropriate to refer to the future numbers of elderly home owners in the Netherlands. Figure 1 indicates the age 
structure of home owners in the Netherlands in 1971, 1977 and 1985. Both in terms of the proportion of home owners and the absolute number of households, the 35-44 age group is an important cohort in the further development of home ownership in the Netherlands. By the year 2000 this cohort will be aged 50-60. The two age cohorts ahead of them - those aged 60-69 and 70-79 in the year 2000 - are also larger cohorts with higher rates of home ownership than the age cohorts ahead of them. Unless there is a significant movement from owning to renting, the absolute number and proportion of the elderly who are home owners will be much higher in the future than it currently is.

A key element in this discussion is the rate of movement of owners to the rented sector. In the Netherlands there are no restrictions on home owners moving to the social rented sector. Indeed, while income restrictions affect

Figure 1 Number and percentage of home owners by age cohort in the Netherlands in 1971, 1977 and 1985

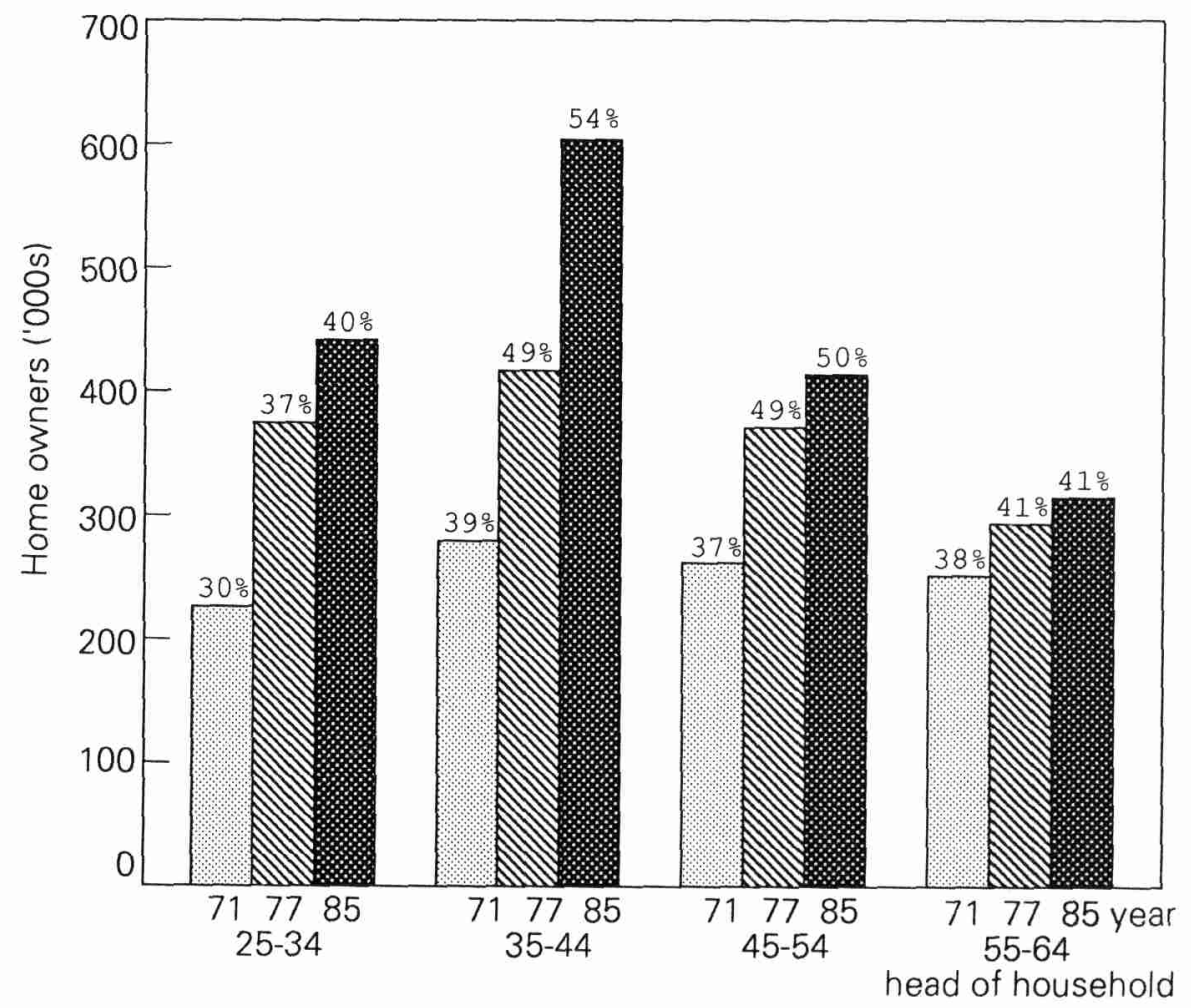

Source: CBS 
access by younger households they are waived for people over 65 . Older people may be in a strong position to obtain rented housing, especially more expensive rented housing. Moreover, there are disincentives (relating to taxation on movement and estate and inheritance taxes) to moving within the owneroccupied sector. At the same time, the social rented sector includes both expensive and cheap rented dwellings, and a considerable stock of good-quality housing. In addition to the attractions of renting, some home owners may wish to release some or all of the equity stored in their property, or they may face problems in maintaining and using their house in old age. While home owners in the Netherlands are generally affluent, low-income owners are a significant and growing group. A marginal home ownership sector has developed and includes people who have become home owners because they could not find suitable housing in the rented sector (Van den Ham and Stouten, 1988). In addition, the longer established home ownership sector in rural areas includes a significant number of detached houses owned by low-income households (Stoppelenburg et al., 1987). This sector probably already includes older, poor home owners and has some problems of disrepair. This has implications for the discussion of elderly home owners, both in relation to the likelihood that some properties will have been less than adequately maintained and to the fact that some elderly owners will have very low incomes in retirement.

\section{Home Owners' Property Values and Movers' Destinations}

The remainder of this paper draws on data from the 1985 National Housing Survey (Woningbehoefte Onderzoek) to develop a fuller picture of residential mobility and tenure choice among elderly people. Rather than being satisfied with the view that older households are immobile, our concern is to assess differences in directions of movement among households in the reduction stage of the life cycle. The major focus is on groups of home owners with different levels of housing equity. From the National Housing Survey we selected households aged 55 or over. After briefly comparing the relative propensity to move of former tenants and home owners, the paper focuses on household movement among elderly home owners.

The data from the 1985 National Housing Survey distinguish between households who moved in 1982 or later and those who did not. As has been shown elsewhere, among older people tenants were more likely to have moved than owners (Hooimeijer et al., 1988); 9.5\% of households which had previously owned their home had moved, compared with $14.8 \%$ of those which had rented their home. For owners, the propensity to move does not vary significantly with income, household structure, employment status or the value of their dwelling.

For flows between and within tenures the patterns of movement are much clearer. Only $2 \%$ of all the tenants who moved in the over 55 age group moved to the owner-occupied sector. This confirms the earlier argument that the growth in home ownership occurs among younger families and that the increasing number of elderly people in the owner-occupied sector arises as a result of the ageing of households already in that sector. 
Almost 57\% of home owners over 55 who moved house between 1982 and 1985 moved to the rented sector. Tables 1 to 4 show that, irrespective of the value of the property which they sold, employment status, household composition, income and age all affect the destination of those moving. Elderly home owners who are not employed are more likely to move to rented housing or to cheaper properties than those still in employment (Table 1). Seventy-five per cent of those not in employment and moving from cheaper dwellings move to the rented sectors. In contrast only 30\% of such households moving from relatively expensive housing move to rented housing. There are a variety of influences here. Leaving the labour force relaxes one constraint on relocation, but the decision to change the type of housing one lives in will also be affected by different space requirements, as a result of decreased household size, or changes in income, expenditure and activities. In addition, however, these results are consistent with the view that households owning more expensive houses have a wider range of choice of subsequent housing destinations and are more likely to select more expensive options. This picture also holds true for elderly home owners in employment. There is a considerable difference in the destination of moves between those owning relatively cheap properties and those owning relatively expensive properties. The latter do not move to low rent housing; they predominantly buy relatively expensive dwellings.

Single-person home owners rarely move within the owner-occupied sector if they have not lived in expensive housing before (Table 2). The effect of the value of the previous dwelling is even more striking among couples than among single-person households. The owners of a dwelling worth $f 175,000$ or more move predominantly within the owner-occupied sector, while $70 \%$ of the households owning low-priced dwellings move to the rented sector. A similar pattern emerges in relation to income (Table 3). Low-income home owners generally move to the rented sector if the value of their previous property is low. Higher-income households also tend to move into the rented sector if the price of their previous dwelling is low. Nearly $40 \%$ of those moving who have an income in excess of $f 38,000$ and live in dwellings worth less than $f 125,000$ move to cheap rented housing. This is completely contrary to the recently formulated intentions of housing policy in the Netherlands. Although this policy does not seek to prohibit movement from the owner-occupied to the rented sector, it does aim to reduce the flow of higher-income households into rented housing with a low monthly rent (of $f 450$ or less). A possible explanation for this unexpected flow is the limited availability of dwellings suited to the needs of the elderly in the more expensive rented sector and the less expensive part of the owner-occupied sector. Where home owners are selling more expensive dwellings they only move to cheap rented housing when they are in the lowest income group. A significant minority of the most equity rich households, however, do move to other parts of the rented sector. 
Table 1 Elderly home owners moving house. Origins and destinations, by employment status $(\%)$

\begin{tabular}{|c|c|c|c|}
\hline & \multicolumn{3}{|c|}{ Value of the previous property ( $\left.f^{\prime} 000 \mathrm{~s}\right)$} \\
\hline & $<125$ & $125-175$ & $>175$ \\
\hline Employed & (7.4) & (17.4) & (17.7) \\
\hline \multicolumn{4}{|l|}{ Destination: } \\
\hline Rent $<f 450$ per month & 26.7 & - & - \\
\hline Rent $>f 450$ per month & 19.0 & 18.5 & 23.3 \\
\hline Own $<f 125,000$ & 26.1 & 17.5 & 3.9 \\
\hline Own $f 125,000-f 175,000$ & 13.4 & - & 5.2 \\
\hline Own $>f 175,000$ & 14.9 & 64.0 & 67.7 \\
\hline Not employed & $(92.6)$ & $(82.6)$ & $(82.3)$ \\
\hline \multicolumn{4}{|l|}{ Destination: } \\
\hline Rent $<f 450$ per month & 39.0 & 39.4 & 5.0 \\
\hline Rent $>f 450$ per month & 37.5 & 19.2 & 24.9 \\
\hline Own $<f 125,000$ & 13.3 & 18.8 & 20.1 \\
\hline Own $f 125,000-f 175,000$ & 5.3 & 12.0 & 12.6 \\
\hline Own $>f 175,000$ & 5.0 & 10.6 & 37.4 \\
\hline
\end{tabular}

Source: WBO 1985/86

Table 2 Elderly home owners moving house. Origins and destinations, by household type (\%)

\begin{tabular}{lrrr}
\hline & $\begin{array}{r}\text { Value of the previous property }\left(f^{\prime} 000 \mathrm{~s}\right) \\
<125\end{array}$ & $125-175$ & $>175$ \\
\hline Single & $(50.1)$ & $(41.8)$ & $(31.1)$ \\
& & & \\
Destination: & & & \\
Rent $<f 450$ per month & 43.6 & 44.0 & 10.1 \\
Rent $>f 450$ per month & 36.1 & 25.3 & 33.8 \\
Own $<f 125,000$ & 14.0 & 23.3 & 37.7 \\
Own $f 125,000-f 175,000$ & 3.9 & 7.5 & 6.7 \\
Own $>f 175,000$ & 2.4 & - & 11.6 \\
& & & \\
Couple & $(49.9)$ & $(58.2)$ & $(68.9)$ \\
& & & \\
Destination: & & & \\
Rent $<f 450$ per month & 32.9 & 24.4 & 1.3 \\
Rent $>f 450$ per month & 36.5 & 14.7 & 20.5 \\
Own $<f 125,000$ & 13.6 & 15.2 & 8.0 \\
Own $f 125,000-f 175,000$ & 7.9 & 11.6 & 13.4 \\
Own $>f 175,000$ & 9.1 & 34.1 & 56.8 \\
\hline
\end{tabular}

Source: WBO 1985/86 


\begin{tabular}{|c|c|c|c|}
\hline & Value of the previ & us propert & f'000s) \\
\hline & $<125$ & $125-175$ & $>175$ \\
\hline Income $<f 21,000$ & $(51.3)$ & $(40.1)$ & $(32.3)$ \\
\hline Destination: & & & \\
\hline Rent $<f 450$ per month & 48.7 & 59.3 & 12.6 \\
\hline Rent $>f 450$ per month & 35.4 & 24.2 & 30.5 \\
\hline Own $<f 125,000$ & 14.2 & 13.0 & 24.7 \\
\hline Own $f 125,000-f 175,000$ & 1.0 & 3.5 & 9.0 \\
\hline Own $>f 175,000$ & 0.8 & - & 23.2 \\
\hline Income $f 21,000-f 29,000$ & $(24.4)$ & $(22.2)$ & $(14.7)$ \\
\hline Destination: & & & \\
\hline Rent $<f 450$ per month & 30.9 & 24.5 & - \\
\hline Rent $>f 450$ per month & 33.3 & 6.1 & 14.4 \\
\hline Own $<f 125,000$ & 15.8 & 41.6 & 23.7 \\
\hline Own $f 125,000-f 175,000$ & 13.2 & 21.3 & 10.0 \\
\hline Own $>f 175,000$ & 6.7 & 6.6 & 51.9 \\
\hline Income $f 29,000-f 38,000$ & $(14.1)$ & $(10.9)$ & $(16.3)$ \\
\hline Destination: & & & \\
\hline Rent $<f 450$ per month & 11.6 & 15.3 & - \\
\hline Rent $>f 450$ per month & 47.6 & 32.3 & 24.2 \\
\hline Own $<f 125,000$ & 14.8 & 37.8 & 29.9 \\
\hline Own $f 125,000-f 175,000$ & 10.6 & - & 10.9 \\
\hline Own $>f 175,000$ & 15.2 & 14.6 & 35.0 \\
\hline Income $>\mathbf{f 3 8 , 0 0 0}$ & $(10.1)$ & $(26.8)$ & $(36.7)$ \\
\hline Destination: & & & \\
\hline Rent $<f 450$ per month & 38.3 & 6.4 & - \\
\hline Rent $>f 450$ per month & 30.5 & 16.8 & 23.7 \\
\hline Own $<f 125,000$ & 9.8 & - & 2.5 \\
\hline Own $f 125,000-f 175,000$ & 6.4 & 14.2 & 14.0 \\
\hline Own $>f 175,000$ & 15.0 & 62.6 & 59.7 \\
\hline
\end{tabular}

Source: WBO 1985/86

The relationship between the value of the previous dwelling and the destination of those moving is also affected by age, although those with substantial equity still have a different pattern of movement (Table 4). These results must be regarded with caution. The number of heads of households aged 75 and over moving from one independent dwelling to another is limited, and the low cell counts for some observations increase the margin of error. The interpretation of the age-effect must also take into account the links between age and employment status, household size, income and health. A more detailed analysis showed that the effect of age largely disappears when controlling for these variables. 


\begin{tabular}{|c|c|c|c|}
\hline & \multicolumn{3}{|c|}{ Value of the previous property ( $f^{\prime} 000 \mathrm{~s}$ ) } \\
\hline & $<125$ & $125-175$ & $>175$ \\
\hline Age 55-64 & (31.3) & $(50.9)$ & $(50.7)$ \\
\hline \multicolumn{4}{|l|}{ Destination: } \\
\hline Rent $<f 450$ per month & 33.5 & 18.6 & 1.8 \\
\hline Rent $>f 450$ per month & 29.3 & 20.8 & 20.2 \\
\hline Own $<f 125,000$ & 10.9 & 17.5 & 18.6 \\
\hline Own $f 125,000-f 175,000$ & 12.7 & 18.6 & 14.8 \\
\hline Own $>f 175,000$ & 13.6 & 24.6 & 44.5 \\
\hline Age 65-74 & (43.7) & $(30.5)$ & (33.2) \\
\hline \multicolumn{4}{|l|}{ Destination: } \\
\hline Rent $<f 450$ per month & 32.5 & 37.4 & 9.5 \\
\hline Rent $>f 450$ per month & 40.7 & 23.5 & 19.1 \\
\hline Own $<f 125,000$ & 19.1 & 13.4 & 16.8 \\
\hline Own $f 125,000-f 175,000$ & 4.4 & 1.5 & 5.0 \\
\hline Own $>f 175,000$ & 3.3 & 24.1 & 49.6 \\
\hline Age $\geq 75$ & $(25.0)$ & (18.6) & (16.1) \\
\hline \multicolumn{4}{|l|}{ Destination: } \\
\hline Rent $<f 450$ per month & 53.6 & 62.9 & \\
\hline Rent $>f 450$ per month & 36.5 & 7.3 & 50.0 \\
\hline Own $<f 125,000$ & 9.9 & 29.8 & 14.0 \\
\hline Own $f 125,000-f 175,000$ & - & - & 13.0 \\
\hline Own $>f 175,000$ & - & - & 23.0 \\
\hline
\end{tabular}

Source: WBO 1985/86

The problems in interpreting the independent effect of age are also apparent in the case of other variables. While employment status, household size and income have effects irrespective of the value of the previous property, the independent effect or relative importance of each remains unclear.

\section{A Multivariate Description}

Various methods can be used to provide the multivariate description which would clarify this picture. The most commonly applied method is probably the logit model. This method requires a transformation of the dependent variable, however, and this makes a direct interpretation of the resulting parameters difficult, especially when the dependent variable has more than two categories, as is the case here. We have therefore used the less elaborate though more easily interpretable approach offered by the ANOTA model (Keller and Verbeek, 1984).

The coefficients of the ANOTA model can be interpreted in the same way as 
the coefficients in a multiple regression model. The coefficient (of, for instance, household size) can be interpreted as the net effect, after the removal of the effects of other variables (income for instance), because the effects are computed as if the income distribution is the same in each household size category. In other words, it is assumed that the explanatory variables are independent of each other.

If a strong association exists between the explanatory variables then the results of the ANOTA model are misleading. This is certainly the case here with household size and household income. Pearson's rank correlation coefficient is as high as 0.5 , which indicates a close association between the two variables. An obvious solution to this problem is to combine the two variables to form one new variable. Once associations between the explanatory variables are isolated, the coefficients of the various explanatory variables can be added to evaluate the combined effect.

Due to the absence of a (logit)transformation of the dependent variable the addition of the ANOTA coefficients can result in values less than zero. This major drawback of the model can only be overcome by reducing the number of categories in the analysis and disregarding variations that might be relevant.

The results of the ANOTA model are shown in Table 5. Value of property at origin, income and household size have been chosen as the explanatory variables because we have assumed that the latter two are the underlying dimensions of the age and employment status effect. Household size and income were combined because of their close association. Few single-person households had an income of $f 38,000$ or more. They were included with those on middle median incomes. Before running the model the level of association between the combined income/household variable and the value of property at origin variable was checked. This turned out to be low (Pearson's rank correlation coefficient was less than 0.25 ).

Interpreting the results is straightforward. For example, on average $26.8 \%$ of all movers opted for a cheap rented dwelling (Table 5). If the mover was a oneperson household with a low income, this probability was increased by $13.3 \%$. If the mover also happened to live in a dwelling worth less than $f 125,000$ then the probability was increased by another $9.3 \%$, resulting in a total probability for this group of moving to a cheap rented dwelling of $49.4 \%(26.8+13.3+9.3)$. The probability of couples with a high income moving from an expensive dwelling to another expensive dwelling was $64.7 \%(19.5+27.4+17.8)$.

The probability of those single persons on low incomes moving from cheap to expensive dwellings was slightly negative, as were the probabilities of median and high-income couples and median and high-income single persons moving from expensive owner-occupied property to cheap rented dwellings.

There is an interesting relationship between the combined household size and income variable and the mover's destination. Small low-income households moved to cheap rented housing to the same extent as larger low-income households. The probability of buying an expensive dwelling was much lower in the case of single persons at all levels of income. 
Table 5 Results of the ANOTA analysis

ANOTA coefficient for household type and income combined

\begin{tabular}{|c|c|c|c|c|c|c|}
\hline & Average & & Single & & Couple & \\
\hline Destination & & low & $\begin{array}{r}\text { median/ } \\
\text { high }\end{array}$ & low & median & high \\
\hline Rent $<f 450$ per month & 26.8 & 13.3 & -5.3 & 13.4 & -18.9 & -13.1 \\
\hline Rent $>f 450$ per month & 29.9 & 3.3 & 2.9 & -0.4 & -2.6 & -3.6 \\
\hline Own $<f 175,000$ & 23.8 & 0.6 & 9.0 & -9.6 & 9.3 & -10.7 \\
\hline Own $>f 175,000$ & 19.5 & -16.2 & -8.3 & -3.4 & 4.2 & 27.4 \\
\hline
\end{tabular}

ANOTA coefficient for property value

\begin{tabular}{lcrrr}
\hline \multirow{2}{*}{ Destination } & \multicolumn{3}{c}{ Value of the previous property $(f$ '000s) } \\
& Average & $<125$ & $125-175$ & $>175$ \\
\hline Rent $<f 450$ per month & 26.8 & 9.3 & 7.2 & -20.3 \\
Rent $>f 450$ per month & 29.9 & 6.2 & -18.9 & -4.5 \\
Own $<f 175,000$ & 23.8 & -6.8 & 5.5 & 7.2 \\
Own $>f 175,000$ & 19.5 & -9.7 & -1.7 & 17.8 \\
\hline
\end{tabular}

Source: WBO 1985/86

The combined income and household size variable and the value of the previous property both have a substantial effect. Except for the effect owning a medianpriced dwelling has on moving to expensive rented dwellings, all the coefficients have the expected sign and a clear pattern of association with the direction of moves. Our findings can be summarized as follows:

- Low-income owners move to cheap rented dwellings most often. In addition, many of them end up in expensive rented housing. If the low-income household consists of a couple then the probability of buying an expensive dwelling is only slightly less than average, in contrast to those households consisting of single persons.

- Home owners on middle incomes tend to move to moderately-priced owneroccupied housing. Single persons are more likely than couples to move to rented housing however.

- Only households in the highest income bracket ( $f 38,000$ or more) are clearly overrepresented in moves to expensive owner-occupied housing.

- Households living in cheap to moderately-priced owner-occupied housing often move to cheap rented housing. The effect of having a high income is to reduce this flow to the rented sector.

- Leaving the owner-occupied sector is particularly common among households in low-priced housing. If these households consist of solitaries then the probability of staying in the owner-occupied sector falls to zero.

- Owning an expensive home has a pervasive effect on housing choice. The 
probability of moving into cheap rented housing is almost zero. The flow to expensive rented housing is less than average. Although a large number of these households move to a less expensive dwelling in the owner-occupied sector, they also have the highest probability of buying an expensive dwelling.

- The highest probability of moving to any particular type of dwelling is that relating to high-income households consisting of couples moving from an expensive dwelling to another expensive dwelling (64.7\%).

- Despite the flow of high-income households to the rented sector, the general pattern is one of segmentation. Households with high incomes and high asset values in the form of their previous home move to very different types of housing than other home owners or tenants when they move.

\section{Conclusions}

Older home owners are less likely to move than younger households and those in the rented sector. They do move sufficiently, however, to have an impact on the housing market. Neither age, income, employment nor household characteristics adequately accounts for the pattern of movement. The value of the property of elderly home owners also has an important effect on housing choice. We know from previous studies that tenants who move in old age mainly move to other rented housing.

Among elderly home owners differences in levels of income and property values lead to divergent patterns of movement. Those with a low equity in the house which they own move into rented housing in significant numbers. These households have less choice in the home ownership market, but they may also wish to use the equity stored in the house for other purposes (especially if their income is low). Households with high incomes or expensive housing remain home owners and remain in or even move to the expensive sector of the market. This effect is less pronounced among solitaries. The net effect of these processes is that the most affluent, equity rich, home owners follow a very different housing career. Other home owners tend to move to rented housing, and especially to expensive rented housing.

The evidence that household size, income and equity, each contribute to an explanation of the housing market behaviour of elderly persons is of considerable interest in the light of population trends. The characteristics of elderly households will change rapidiy in the near future (Hooimeijer and Linde, 1988). The proportion of one-person households among the elderly is increasing due to the growing discrepancy in the life expectancy of males and females and the rise in divorce rates among the young, particularly during the 1970s. The average incomes of the elderly are likely to improve only slightly over the coming decades (Pommer, 1990). The decrease in the real value of old age benefits, the increase in unemployment in the $1970 \mathrm{~s}$, and early retirement will all serve to reduce the value of old age pensions. Moreover, the relatively constant average level of income among the elderly obscures the fact that income inequalities among the elderly are increasing rapidly.

Alongside these changes there will be an increasing number of elderly home 
owners. Hooimeijer and Linde (1988) estimate that the proportion of single elderly who are home owners will increase from $25 \%$ in 1982 to $35 \%$ by 2000 . In the case of larger households the increase will be from $40 \%$ to $55 \%$.

This article suggests that there will be an increased polarization in the housing choice of those elderly households who own a house. It is important to anticipate a demand from home owners with substantial market power deriving from the value of their property. Many of these will seek different housing in the owner-occupied sector. It is not clear how far this sector currently meets the housing preferences of these home owners. Would more move within the owneroccupied sector rather than to the rented sector if there were different properties with different locations, prices and services available? And would this release housing for others? Generating such turnover in the housing market could be a more effective way of providing housing for other younger households than constructing new housing.

At the same time, and especially if the evidence on moves by home owners who live alone and those who have low-value property is regarded as evidence of preference, many home owners will want to move to the rented sector. What these data do not disclose is the nature of the pressures on home owners to move. Such pressures could be associated with the high costs of running and maintaining existing homes (especially where these are larger and older dwellings). Some of the movement of owner-occupiers to the rented sector may be affected by this. If planning for the rented sector does not envisage (for whatever reasons) such moves by the increasing number of elderly home owners, then these households are likely to experience real problems. Their ability, in some cases, to compete with other households will also create problems of access to the housing market for others. This may be especially relevant for suburban areas in the Netherlands, where the increase in the number of elderly home owners can be expected to be large and the supply of rented housing is low. The need to develop a policy for elderly home owners is likely to become an important issue.

Note

(1) This article was written when Alan Murie held the Belle van Zuylen chair at the University of Utrecht.

\section{References}

Deurloo, M.C. et al. (1987), "Tenure Choice in the Dutch Housing Market", Environment and Planning A (19), pp. 763-781.

Dieleman, F.M. (1986), "The Future of Dutch Housing: a Review and Interpretation of the Recent Literature", Tijdschrift voor Economische en Sociale Geografie (77), pp. 336-344.

Dieleman, F.M. et al. (1986), "Demographic Impacts on the Netherlands Housing System", Netherlands Journal of Housing and Environmental Research (1), pp. 69-82. 
Ham, C. van den, and P. Stouten (1988), "Urban Renewal in Rotterdam: Changing Conditions and Perspectives", Netherlands Journal of Housing and Environmental Research (3), pp. 241-257.

Hooimeijer, P., and F.M. Dieleman (1986), Huishoudens in de Reductiefase en de Woonruimteverdeling, Zoetermeer: Ministerie van Volkshuisvesting, Ruimtelijke Ordening en Milieubeheer.

Hooimeijer, P. et al. (1986), "Households in the Reduction Stage: Implications for the Netherlands Housing Market", Housing Studies (1), pp. 195-209.

Hooimeijer, P. et al. (1988), "Residential Mobility of Households in the Reduction Stage in the Netherlands", Tijdschrift voor Economische en Sociale Geografie (79), pp. 306-318.

Hooimeijer, P., and M. Linde (1988), Vergrijzing, Individualisering en de Woningmarkt; Het Wodyn Simulatiemodel, Utrecht: Faculteit der Ruimtelijke Wetenschappen.

Keller, W.J., and A. Verbeek (1984), "ANOTA: Analysis of Tables", Kwalitatieve Methoden (15), pp. 1-6.

Pommer, E. (1990), Inkomens op leeftijd, Alphen aan den Rijn: Samsom.

Serail, S. (1988), Huisvesting en (Gewenste) Verhuizingen van Oudere Huishoudens, Zoetermeer: Ministerie van Volkshuisvesting, Ruimtelijke Ordening en Milieubeheer.

Stoppelenburg, P. et al. (1987), "Maintenance of Owner Occupied Houses: a Base for Co-operation?", Netherlands Journal of Housing and Environmental Research 2, pp. 215-232. 